\title{
ЕКОНОМІКО-МАТЕМАТИЧНА МОДЕЛЬ ОПТИМАЛЬНОГО КЕРУВАННЯ ТАРИФІКАЦИЙНОЮ СИСТЕМОЮ СТРАХОВОЇ КОМПАНІї
}

\section{ЭКОНОМИКО-МАТЕМАТИЧЕСКАЯ МОДЕЛЬ ОПТИМАЛЬНОГО УПРАВЛЕНИЯ ТАРИФИКАЦИОННОЙ СИСТЕМОЙ СТРАХОВОЙ КОМПАНИИ}

\section{ECONOMIC-MATHEMATICAL MODEL FOR OPTIMAL CONTROL OF TARIFFICATION SYSTEM OF INSURANCE COMPANY}

В статті викладено авторські розробки економіко-математичної моделі, яка пропонує формалізований математичний підхід до визначення необхідних управлінських рімень щзодо змін у тарифікаційній системі страхової компанії з метою утримання портфеля страхових договорів в рамках бажаного рівня прибутковості. $B$ статті наводиться математична формалізація поняття «тарифікаиійна система», описано, яким чином можна математично врахувати якісні характеристики об 'єктів страхування, щзо описують ступінь ризику пов'язаний з останніми. Також у статті наведено методи обрахунку значень основних фінансових потоків, щчо мають місие для страхової компанії; приведено варіант розрахунку такого фінансового показника як комбінований коефіцієнт збитковості та наведена якісна характеристика всіх можливих кількісних значень даного показника. Головним результатом і новизною статті є дискретна модель оптимального керування тарифікаційною системою страхової компанї, яка за умов застосування в практичній діяльності страхової компанії може виступати в ролі апарату підтримки прийняття рішень. Також наводяться переваги і недоліки отриманої моделі.

Ключові слова: страхування, економіко-математична модель, страхова компанія як об'єкт керування, тарифікаційна система, теорія оптимального керування.

В статье приведены авторские разработки экономико-математической модели, которая предлагает формализованный математический подход $\kappa$ определению необходимых управленческих решений касательно изменений в тарификационной системе страховой компании с иелью удержания портфеля страховых договоров в рамках желаемого уровня прибыльности. В статье приводится математическая формализачия понятия «тарификационная система», описывается, каким образом можно математически учитывать качественные характеристики объектов страхования, которые описывают степень риска связанного с последним. Также в статье приведены методы расчёта значений основных финансовых потоков, которые имеют место для страховой компании; приведён вариант расчёта такого финансового показателя как комбинированный коэффициент убыточности и приведена качественная характеристика всех возможных количественных значений данного показателя. Главным результатом $u$ новизной статьи является дискретная модель оптимального управления тарификационной системой страховой компании, которая при условии применения в 
практической деятельности страховой компании может выступать в роли аппарата поддержки принятия решений. Также приведены преимущества и недостатки полученной модели.

Ключевые слова: страхование, экономико-математическая модель, страховая компания как объект управления, тарификационная система, теория оптимального управления.

This paper describes the authors works at economic-mathematical model that provides a formal mathematical approach to determine the appropriate management decisions about changes in ratification system of insurance company to hold a portfolio of insurance contracts under the desired level of profitability. This paper describes the mathematical formalization of the concept of "ratification system", describes how to mathematically take into account the qualitative characteristics of objects of insurance, describing the risk associated with the latter. Also, the paper presents methods for calculating the basic financial flows that take place for an insurance company; given variant of calculating such financial indicator as a combined loss ratio and describes qualitative characteristics for all possible numerical values of this index. The main result and novelty of the paper is discrete model for optimal control of ratification system of insurance company that if used in the practice of the insurance company can act as a decision support system. Also, there are advantages and disadvantages of the resulting model.

Keywords: insurance, economic-mathematical model, insurance company as an object of control, ratification system, optimal control theory.

Вступ. Формування уявлення про мікроекономічні системи як об'єкти керування дає широкі можливості для створення математичних моделей, що описують дані системи та дають змогу створювати потужні системи підтримки прийняття рішень, зокрема на базі теорії оптимального керування. Особливі перспективи використання таких систем має по відношенню до страхового бізнесу, що обумовлено наявністю процесів, які напряму впливають на фінансовий стан страхової компанії і при цьому погано піддаються прогнозуванню. Мова йде про випадковий характер виникнення страхових випадків, за якими страхова компанія несе відповідальність.

В першу чергу, існує проблема з визначенням «ціни питання» - системи страхових тарифів (тарифікаційної системи), які б забезпечували стабільне зростання капіталу страхової компанії. Для досягнення цієї мети в умовах невизначеності, що породжується випадковим характером страхових випадків і відповідних виплат за ними, тарифікаційна система страхової компанії також мусить постійно змінюватись у відповідності до поточної ситуації. Під зміною тарифікаційної системи мається на увазі не встановлення тарифу для кожного окремо взятого клієнта, i навіть не встановлення тарифів для окремих сегментів ринку, важливо розглядати портфель страхових договорів як цілісну систему, в якій все взаємопов'язано.

Ефективним варіантом для втілення вищезгаданої ідеї в життя може бути побудова математичних моделей, що можуть дати відповідь на питання про 
те, яким чином необхідно змінювати тарифікаційну систему i як це виражається в кількісних характеристиках страхової компанії.

Про актуальність даного напрямку досліджень та застосування теорії оптимального керування до страхового бізнесу свідчить зацікавленість ним серед вітчизняних та зарубіжних вчених. Провідне місце серед них належить виключно західним науковцям, зокрема варто відмітити наступні роботи: «Pricing General Insurance Using Optimal Control Theory" (Paul Emms, Steven Haberman), "Stochastic Control Theory For Optimal Investment" (Maritina T. Castillo, Gilbert Parrocha), "Stochastic Control in Insurance" (Hanspeter Schmidli), "Stochastic Control with Application in Insurance" (Christian Hipp, Kerry Back, Tomasz R. Bielecki, Shige Peng, Walter Schachermayer), "Optimal Risk/Dividend Distribution Control Models. Applications to Insurance" (Michael I. Taksar). A також уваги варті роботи російського вченого Ніколенко Н.П. («Стратегическое управление страховой компанией», «Системный менеджмент в страховой компании: роль финансового управления»), які хоч $\mathrm{i}$ не підкріплені потужним математичним апаратом, але досить детально розглядають процес стратегічного i фінансового керування страховою компанією. Серед представників вітчизняної науки варто відмітити роботи Конохової Ю.В. (НТУ «Харківський політехнічний інститут»), Шевчука О.О. (Львівський банківський інститут НБУ), представників Міжнародного центру наукових досліджень теорії i практики страхування (Козьменко О.В., Козьменко С.М., Бойко А.О. та інших), а також дослідження Волошина I. та Волошина М. («Керування депозитною діяльністю багатопродуктового банку», «Оцінка оптимальних ставок за роздрібненими строковими вкладами банку»), що ідейно і методологічно мали значний вплив на дане дослідження.

Постановка завдання. Серед задач, що були поставлені під час дослідження, можна виділити такі:

- Проведення аналізу функціонування страхової компанії як об'єкта керування, в якому керування здійснюється шляхом цілеспрямованого впливу на iї тарифікаційну систему. Частково результати цього аналізу вже були опубліковані раніше [1], дана стаття лише доповнить їх.

- Розробка економіко-математичної моделі оптимального керування тарифікаційною системою страхової компанії, яка б була в змозі дати обгрунтовану математично відповідь на питання про те, яким чином необхідно змінювати тарифікаційну систему страхової компанії або деяку ii частину для досягнення бажаного рівня прибутковості в поточних ринкових умовах.

Методологія. Для реалізації поставлених в рамках дослідження задач було використано інструментарій теорії множин, теорії оптимального керування (зокрема в плані постановки дискретних задач оптимального 
керування), а також в дослідженні застосовано ряд фінансових та актуарних коефіцієнтів та показників.

Результати дослідження. Для початку визначимо яким вимогам має відповідати економіко-математична модель управління тарифікаційною системою страхової компанії. Перш за все, модель має бути орієнтована на можливість їі практичного застосування, а не тільки як теоретична побудова, яка в загальних формулах описує певне явище. Відповідно до цього, одним із основоположних принципів майбутньої моделі має бути використання тих показників та даних, які реально використовуються в сучасних страхових компаніях, які займаються страхуванням ризиків, а відповідно $i$ наявні $в$ управлінській звітності останніх, а також в їхніх базах даних. Саме тому, одним із припущень моделі $\epsilon$ наявність таких даних, при чому, наявність їх для всіх рівнів функціонування страхової компанії (від окремих договорів страхування до портфеля договорів у розмірах окремих видів страхування).

Модель створюється для аналізу стану страхової компанії та визначення оптимального управління іiі тарифікаційною системою через певні проміжки часу. Тобто модель $\epsilon$ динамічною, так як розглядає динаміку зміни стану страхової компанії та управління іiі тарифікаційною системою з часом, а рішення, прийняті в кожен момент часу певною мірою впливають на майбутні результати діяльності компанії i, як наслідок, на всі наступні рішення, що приймаються в даному контексті. При цьому варто зауважити, що описана далі модель являється дискретною в часі.

Також необхідно зауважити, що під тарифікаиійною системою страхової компанії будемо розуміти перелік факторів ризику та категорій об'єктів, що страхуються за відповідними їм тарифними ставками та умови їх застосування, визначені для певних однорідних груп ризиків, що пропонуються для страхування, або видів страхування чи страхових програм.

Тоді, з математичної точки зору можна представити тарифікаційну систему наступним чином:

$$
\Theta\left(\theta_{b}(t), H, K(t), t\right),
$$

Де: $\theta_{b}(t)$ - множина базових тарифів в момент часу $t$.

$H$ - множина факторів ризику.

$K(t)$ - множина коефіцієнтів поправки базового тарифу на фактори ризику в момент часу $t$.

Під базовими тарифами будемо розуміти тарифну ставку, яка $\epsilon$ відправною точкою для подальших розрахунків тарифу для кожного індивідуального договору. Базові тарифи постійно змінюються в часі. Більше того, в рамках даної моделі вважаємо, що множина базових тарифів $\epsilon$ множиною змінних на які можна здійснювати керуючий вплив. 
Введемо позначення. Нехай, індексами $q$ позначатимемо види страхування, індексами $p$ - страхові програми, індексами $s$ - сегменти, а індексами $o-$ договори.

Тоді:

$q \in\left[1 ; n_{q}\right]$, де $n_{q}$ - кількість видів страхування в загальному портфелі компанії;

$p \in\left[1 ; n_{p, q}\right]$,де $n_{p, q}-$ кількість страхових програм в $q$-му виді страхування;

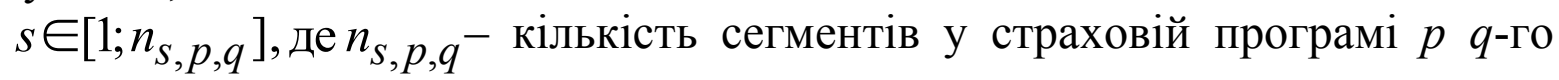
виду страхування;

$o \in\left[1 ; n_{o, s, p, q}\right]$, де $n_{o, s, p, q}$ - кількість договорів у сегменті s, страхової програми $p q$-го виду страхування.

Варто зауважити, що під сегментом в рамках даного дослідження будемо розуміти групу договорів страхування, що мають унікальний набір наступних характеристик:

1) Відносяться до однієї страхової програми певного виду страхування;

2) Об'єкти страхування за такими договорами однаково характеризуються щодо ризику, який вони в собі несуть;

Тоді, використовуючи нові позначення можна в більш детальному вигляді описати вигляд множити базових тарифів. Якщо базові тарифи визначаються по одному на увесь вид страхування:

$$
\theta_{b}(t)=\left\{\begin{array}{c}
\theta_{b}^{1}(t), \theta_{b}^{2}(t), \ldots, \theta_{b}^{n_{q}}(t) \\
b
\end{array}\right.
$$

Якщо базові тарифи визначаються окремо на кожну страхову програму, то:

$$
\theta_{b}(t)=\left\{\begin{array}{ccc}
\theta_{b}^{1,1}(t) & \ldots & \theta_{b}^{1, n_{q}}(t) \\
\ldots & \ldots & \ldots \\
\theta_{b}^{n_{p, q}, 1}(t) & \ldots & \theta_{b}^{n_{p, q}, n_{q}}(t)
\end{array}\right\}
$$

Сегменти ж, як частина деякої програми або виду страхування повністю успадковують базовий тариф відповідної програми або виду.

Множина факторів ризику - є множиною якісних характеристик об'єктів страхування (клієнтів або їх майна) страхової компанії, які для страхової компанії виступають як фактори, що впливають на ризик. Для кожного виду страхування перелік таких факторів є унікальним. Враховуючи той факт, що всі об'єкти страхування в рамках одного виду страхування належать до 
об'єктів одного класу (людина, автомобіль, квартира і т.д.), то і набори якісних характеристик для них однакові, аналогічно і з сегментами. Тобто, множина факторів ризику складається з множин факторів ризику для кожного окремого виду страхування:

$$
H=\left\{H_{1}, H_{2}, \ldots, H_{n_{q}}\right\}
$$

Кожна така множина містить перелік факторів ризику, які враховуються при страхуванні клієнта. В свою чергу кожен із факторів ризику може приймати одне 3 декількох значень, і лише одне для конкретного клієнта в рамках конкретного договору страхування, тобто:

$$
H_{q}=\left\{H_{q}^{1}, \ldots, H_{q}^{m}\right\}=\left\{\begin{array}{ccc}
h_{q}^{1,1} & \ldots & h_{q}^{m, 1} \\
\ldots & \ldots & \ldots \\
h_{q}^{1, i} & \ldots & h_{q}^{1, j}
\end{array}\right\}
$$

Множини факторів ризику можуть змінюватися лише у дуже особливих виключних випадках, тому в рамках нашої моделі множини факторів ризику вважаємо незмінними в часі.

Множина коефіцієнтів поправки на фактори ризику (множсин коригуючих коефічієнтів) являється кількісним аналогом множин факторів ризику, і використовується для модифікації базового тарифу, щоб урахувати фактори ризику для кожного клієнта. Використання коефіцієнтів поправки на фактори ризику робить тарифікаційну систему гнучкою та зручною для індивідуалізації тарифікації 3 метою найточніше підібрати ціну для конкретних клієнтів. Таким чином реалізується принцип індивідуального підходу до клієнта, який дозволяє надавати більш надійним і менш ризиковим клієнтам знижки, в той час, як більш ризиковим клієнтам створюються надбавки. Тобто, множина коефіцієнтів поправки на фактори ризиків несе в собі вигоди для «гарних» клієнтів і певною мірою захищає страхову компанію від ризиків.

Кожному елементу множини факторів ризику відповідає один елемент множини коефіцієнтів поправки на фактори ризику, отже маємо:

$$
K(t)=\left\{K_{1}(t), K_{2}(t), \ldots, K_{n_{q}}(t)\right\}
$$

Де кожен елемент має наступний вигляд: 


$$
K_{q}(t)=\left\{K_{q}^{1}(t), \ldots, K_{q}^{m}(t)\right\}=\left\{\begin{array}{ccc}
k_{q}^{1,1} & \ldots & k_{q}^{m, 1} \\
\ldots & \ldots & \ldots \\
k_{q}^{1, i} & \ldots & k_{q}^{1, j}
\end{array}\right\}
$$

Аналогічним до (7) чином можна також скласти множину коефіцієнтів поправки на фактори ризику і для окремих страхових програм, якщо в цьому $\epsilon$ потреба.

На відміну, від множини факторів ризику, множина коефіцієнтів поправки на фактори ризику може змінюватись 3 часом за рішеннями того, хто приймає рішення (ТПР), тобто вона також $\epsilon$ множиною змінних на які можна здійснювати керуючий вплив. Однак, для спрощення на даному етапі, приймаємо, що дана множина в рамках моделі є також незмінною в часі.

Тобто, це означає, що множину коефіцієнтів поправок на фактори ризику можна в спрощеному для нашої моделі вигляді представити як:

$$
K(t)=\left\{K_{1}\left(t_{0}\right), K_{2}\left(t_{0}\right), \ldots, K_{n_{q}}\left(t_{0}\right)\right\}
$$

Враховуючи (4) - (8), можемо тепер описати, яким чином визначаються індивідуальні тарифи для кожного з клієнтів. Нехай, маємо деякого клієнта (позначимо його через індекс $o$ ), що бажає застрахуватись за договором $q$-го виду страхування, при цьому, він має набір значень факторів ризику, якому відповідає наступний набір коефіцієнтів поправок на фактори ризику:

$$
K_{o}=\left\{k_{q}^{1}=k_{1}, \ldots, k_{q}^{m}=k_{m}\right\} \in K_{q}(t)
$$

Тоді остаточний тариф розраховується як добуток всіх коефіцієнтів поправки на фактори ризику і на відповідний базовий тариф:

$$
\theta^{o}=\theta_{b} \cdot \prod_{i=1}^{m} k_{q}^{i}
$$

Тепер перейдемо розгляду всіх фінансових потоків, які приймають участь у моделі управління тарифікаційною системою страхової компанії:

$G(t)$ - потік страхових премій на момент часу $\mathrm{t}$.

$C(t)$ - потік комісійних винагород партнерам страхової компанії на момент часу $\mathrm{t}$.

$N(t)$ - потік податкових відрахувань на момент часу $\mathrm{t}$.

$D(t)$ - потік відрахувань на ведення справ та маркетинг на момент часу $\mathrm{t}$.

$V(t)$ - потік страхових виплат клієнтам на момент часу $\mathrm{t}$.

$R(t)$ - сума збитків по страховим випадкам, що знаходяться на етапі врегулювання на момент часу $\mathrm{t}$. 
Почнемо з потоку страхових премій - $G(t)$. Так як модель $є$ дискретною в часі, то значення всіх потоків, включаючи потік страхових премій, фіксуються через певні проміжки часу. Це означає, що під $G(t)$ необхідно розуміти суму премій, яка сформувалася за деякий період $[t-1 ; t]$ із відповідним фіксуванням розміру цієї суми на момент $t$.

Також, необхідно врахувати той факт, що рішення доводиться приймати на основі інформації про конкретний період часу, в той час як премія сплачується, як правило, повністю і одразу після заключення договору. Це пов'язано 3 тим фактом, що страхові випадки можуть наступити в будь-який момент дії договору, а тому необхідно контролювати ситуацію періодично, аналізуючи окремі періоди діяльності компанії. Тому для співвідносності величин необхідно замість сумарної премії використовувати так звану зароблену премію - частину від загальної премії за договором, яка припадає лише на заданий період, якщо уявити, що премія виплачується безперервно і рівномірно протягом всього періоду дії договору [2]. Даний показник широко використовується при визначенні фінансових результатів діяльності страхових компаній за певний період і $є$ загальноприйнятим. Для розрахунку даного показника для окремого договору можна скористатися наступною формулою:

$$
G\left(t_{i-1}, t_{i}\right)^{o, s, p, q}=\left\{\begin{array}{c}
\frac{t_{\text {en }}-t_{i-1}}{t_{\text {en }}-t_{s t}} \cdot G^{o, s, p, q} \text { при } t_{s t} \leq t_{i-1}, t_{i-1} \leq t_{\text {en }} \leq t_{i} \\
\frac{t_{i}-t_{i-1}}{t_{\text {en }}-t_{s t}} \cdot G^{o, s, p, q} \text { при } t_{s t} \leq t_{i-1}, t_{\text {en }}>t_{i} \\
G^{o, s, p, q} \text { при } t_{i-1} \leq t_{s t} \leq t_{i}, t_{i-1} \leq t_{\text {en }} \leq t_{i} \\
\frac{t_{i}-t_{s t}}{t_{\text {en }}-t_{s t}} \cdot G^{o, s, p, q} \text { при } t_{s t} \leq t_{i-1}, t_{\text {en }}>t_{i} \\
0 \text { при }\left[t_{s t} ; t_{e n}\right] \cup\left[t_{i-1} ; t_{i}\right]=\varnothing
\end{array}\right.
$$

Де: $G^{o, s, p, q}$ - загальна премія по окремому договору;

$\left[t_{s t} ; t_{e n}\right]-$ часові межі дії договору;

$\left[t_{i-1} ; t_{i}\right]-$ часові межі періоду, що аналізується.

Загальна премія по окремому договору може бути визначена, виходячи із формули індивідуального тарифу (9):

$$
G^{o, s, p, q}=I^{o, s, p, q} \cdot \theta_{b}^{p, q} \cdot \prod_{i=1}^{m} k_{i}^{o, s, p, q},
$$

Де: $I^{o, s, p, q}-$ страхова сума по окремому договору;

$\theta_{b}^{p, q}-$ базовий тариф який застосовується для даного договору; 
$k_{i}^{o, s, p, q}$ - коефіцієнти поправки на фактори ризику для даного договору.

Таким чином, можна визначити спосіб обрахунку суми заробленої за певний період часу премії для різних рівнів функціонування страхової компанії шляхом поступової агрегації. У вигляді формул це можна зобразити наступним чином:

Для окремого сегмента:

$$
G\left(t_{i-1}, t_{i}\right)^{s, p, q}=\sum_{o=1}^{n_{o, s, p, q}} G\left(t_{i-1}, t_{i}\right)^{o, s, p, q}
$$

Для окремої програми страхування:

$$
G\left(t_{i-1}, t_{i}\right)^{p, q}=\sum_{s=1}^{n_{s, p, q}} \sum_{o=1}^{n_{o, s, p, q}} G\left(t_{i-1}, t_{i}\right)^{o, s, p, q}
$$

Для окремого виду страхування:

$$
G\left(t_{i-1}, t_{i}\right)^{q}=\sum_{p=1}^{n_{p, q}} \sum_{s=1}^{n_{s, p, q}} \sum_{o=1}^{n_{o, s, p, q}} G\left(t_{i-1}, t_{i}\right)^{o, s, p, q}
$$

Загалом по всій компанії:

$$
G\left(t_{i-1}, t_{i}\right)=\sum_{q=1}^{n_{q}} \sum_{p=1}^{n_{p, q}} \sum_{s=1}^{n_{s, p, q}} \sum_{o=1}^{n_{o, s, p, q}} G\left(t_{i-1}, t_{i}\right)^{o, s, p, q}
$$

Аналогічним чином можна описати методи обрахунку значень всіх інших потоків, єдина різниця у способі обрахунку сум відповідних потоків для окремих договорів, тому далі для всіх інших потоків будемо лише зазначати формулу обрахунку для окремого договору та формулу для всього портфеля договорів компанії.

Для потоку комісійних витрат:

Для окремого договору:

$$
C\left(t_{i-1}, t_{i}\right)^{o, s, p, q}=c^{o, s, p, q} \cdot G\left(t_{i-1}, t_{i}\right)^{o, s, p, q}
$$

Загалом по всій компанії:

$$
C\left(t_{i-1}, t_{i}\right)=\sum_{q=1}^{n_{q}} \sum_{p=1}^{n_{p, q}} \sum_{s=1}^{n_{s, p, q}} \sum_{o=1}^{n_{o, s, p, q}} c^{o, s, p, q} \cdot G\left(t_{i-1}, t_{i}\right)^{o, s, p, q}
$$

Де $c^{o, s, p, q}$ - розмір комісійної винагороди за конкретним договором страхування у відсотках від премії.

Для потоку податкових відрахувань:

Для окремого договору:

$$
N\left(t_{i-1}, t_{i}\right)^{o, s, p, q}=v\left(t_{i-1}, t_{i}\right) \cdot G\left(t_{i-1}, t_{i}\right)^{o, s, p, q}
$$

Загалом по всій компанії: 


$$
N\left(t_{i-1}, t_{i}\right)=v\left(t_{i-1}, t_{i}\right) \cdot G\left(t_{i-1}, t_{i}\right)
$$

Де $v\left(t_{i-1}, t_{i}\right)$ - ставка податку на валові премії, дійсна для періоду $\left[t_{i-1} ; t_{i}\right]$

Для потоку відрахувань на ведення справ та маркетинг:

Для окремого договору:

$$
D\left(t_{i-1}, t_{i}\right)^{o, s, p, q}=\left(\alpha\left(t_{i-1}, t_{i}\right)+\beta\left(t_{i-1}, t_{i}\right)\right) \cdot G\left(t_{i-1}, t_{i}\right)^{o, s, p, q}
$$

Загалом по всій компанії:

$$
D\left(t_{i-1}, t_{i}\right)=\left(\alpha\left(t_{i-1}, t_{i}\right)+\beta\left(t_{i-1}, t_{i}\right)\right) \cdot G\left(t_{i-1}, t_{i}\right)
$$

Де $\alpha\left(t_{i-1}, t_{i}\right), \beta\left(t_{i-1}, t_{i}\right)$ - величина відрахувань на ведення справ та на маркетинг у відсотках від премії відповідно, дійсних у період $\left[t_{i-1} ; t_{i}\right]$. Значення цих величин може бути різним для різних частин портфеля страхових договорів, в такому разі варто розбивати потік описаний в (21) на відповідні частини і потім рахувати їх суму.

Цілком очевидно, що компанія має всю інформацію про здійснені нею виплати по страховим випадкам за певний проміжок часу, при цьому вважаємо, що з цих виплачених сум вже було вирахувано суму безумовної та умовної франшизи, якщо це мало місце для конкретного страхового випадку.

Тоді для потоку страхових виплат, для окремого договору:

$$
V\left(t_{i-1}, t_{i}\right)^{o, s, p, q}=\left\{\begin{array}{c}
\sum_{i=1}^{n_{v}} V_{i}\left(t_{i-1}, t_{i}\right)^{o, s, p, q} \text { при } n_{v} \geq 1 \\
0 \text { при } n_{v}=0
\end{array}\right.
$$

Де $n_{v}$ - кількість страхових випадків по заданому договору, що сталися в період $\left[t_{i-1} ; t_{i}\right]$ i по яким було прийняте рішення про виплату.

Загалом по всій компанії:

$$
V\left(t_{i-1}, t_{i}\right)=\sum_{q=1}^{n_{q}} \sum_{p=1}^{n_{p, q}} \sum_{s=1}^{n_{s, p, q}} \sum_{o=1}^{n_{o, s, p, q}} V\left(t_{i-1}, t_{i}\right)^{o, s, p, q}
$$

I аналогічно для суми резервів на момент $t$. Для окремого договору:

$$
R\left(t_{i-1}, t_{i}\right)^{o, s, p, q}=\left\{\begin{array}{c}
\sum_{i=1}^{n_{r}} R_{i}\left(t_{i-1}, t_{i}\right)^{o, s, p, q} \text { при } n_{r} \geq 1 \\
0 \text { при } n_{r}=0
\end{array}\right.
$$

Де $n_{r}-$ кількість страхових випадків по договору, що сталися в період $\left[t_{i-1} ; t_{i}\right]$, але по яким на момент часу $t_{i}$ рішення щодо виплати ще не було прийняте.

Загалом по всій компанії: 


$$
R\left(t_{i-1}, t_{i}\right)=\sum_{q=1}^{n_{q}} \sum_{p=1}^{n_{p, q}} \sum_{s=1}^{n_{s, p, q}} \sum_{o=1}^{n_{o, s, p, q}} R\left(t_{i-1}, t_{i}\right)^{o, s, p, q}
$$

Тепер, коли всі потоки описані та описано процес їх формування на всіх структурних рівнях функціонування страхової компанії, можна скласти дискретну модель оптимального управління тарифікаційною системою страхової компанії.

В ролі фазових змінних (змінні, на які здійснюється керуючий вплив), як вже було зазначено вище, приймаємо множину базових тарифів страхової компанії, загальний вигляд якої для різних варіантів встановлення тарифів було описано в (2) та (3).

Перш за все, необхідно визначити мету здійснення управління тарифікаційною системою. Найпростішим і очевидним варіантом є вимога постійного зростання капіталу страхової компанії з періоду в період.

В цьому може допомогти наступне рівняння, що описує процес формування і зміни капіталу компанії під дією вищеописаних в (10) - (25) фінансових потоків:

$$
X\left(t_{i}\right)=X\left(t_{i-1}\right)+(G-C-N-D-V-R)_{\left[t_{i-1}, t_{i}\right]}
$$

Розмір капіталу компанії на початок періоду $X\left(t_{i-1}\right)$ вважаємо відомим. Тоді за формулою (26) можна відслідковувати динаміку капіталу страхової компанії.

3 іншого боку дуже зручно використовувати такий відносний показник як комбінований коефiuуєнт збитковості (в англомовній літературі - combined ratio), який $є$ одним із показників, що широко використовуються в світовій практиці для оцінки збитковості портфеля страхових договорів або його частини [3]. Він представляє з себе відношення суми витрат по страховим випадкам (виплати та резерви) та інших витрат, не пов'язаних зі страховими випадками, до суми заробленої премії. Позначимо його через $\mu$ :

$$
\mu\left(t_{i}\right)=\frac{(C+N+D+V+R)_{\left[t_{i-1}, t_{i}\right]}}{G\left(t_{i-1}, t_{i}\right)}, \mu\left(t_{i}\right) \geq 0
$$

Так як $G\left(t_{i-1}, t_{i}\right)$ і залежні від нього потоки цілком визначаються тарифікаційною системою компанії, зокрема і множиною базових тарифів, то і комбінований коефіцієнт збитковості цілком визначається тарифікаційною системою.

Даний показник також зручний тим, що може служити індикатором, який показує, яким чином змінюється капітал страхової компанії за той чи інший період часу. Для доведення цієї думки розглянемо, що означають можливі значення даного показника в загальному вигляді: 
- $\Delta X\left(t_{i-1}, t_{i}\right)>0$ при $0 \leq \mu\left(t_{i}\right)<1$ - витрати компанії в сумі менші за суму їі доходів, капітал зростає тим швидше, чим ближче $\mu\left(t_{i}\right)$ до 0.

- $\Delta X\left(t_{i-1}, t_{i}\right)=0$ при $\mu\left(t_{i}\right)=1$ - витрати компанії в сумі рівні сумі ії доходів, капітал залишається незмінним (точка беззбитковості).

- $\Delta X\left(t_{i-1}, t_{i}\right)<0$ при $\mu\left(t_{i}\right)>1$ - витрати компанії в сумі перевищують суму іï доходів, капітал зменшується тим швидше, чим більше $\mu\left(t_{i}\right)$ від 1.

Тобто, на відміну від критерію на основі рівняння (26), комбінований коефіцієнт збитковості дозволяє зрозуміти наскільки ефективною є страхова компанія, наскільки вона далека від стану беззбитковості, а відповідно і від стану збитковості, який після цього може наступити.

Таким чином, тепер можливо визначити, в чому полягає керуючий вплив. Керуючий вплив здійснюється на базові тарифи, і може бути описаний наступною системою рівнянь (у випадку тарифікаційної системи виду (2)):

$$
\left\{\begin{array}{c}
\theta_{b}^{1}\left(t_{i}, t_{i+1}\right)=\theta_{b}^{1}\left(t_{i-1}, t_{i}\right)+u^{1}\left(t_{i}\right) \\
\ldots \\
\theta_{b}^{n_{q}}\left(t_{i}, t_{i+1}\right)=\theta_{b}^{n_{q}}\left(t_{i-1}, t_{i}\right)+u^{n_{q}}\left(t_{i}\right)
\end{array}\right.
$$

Або у векторній формі:

$$
\bar{\theta}_{b}\left(t_{i}, t_{i+1}\right)=\bar{\theta}_{b}\left(t_{i-1}, t_{i}\right)+\bar{u}\left(t_{i}\right)
$$

При цьому, базові тарифи можуть змінюватись лише в певних межах. Відповідно, ці обмеження визначають і обмеження на керуючий вплив. Запишемо ці обмеження також у векторній формі:

$$
\bar{\theta}_{\min } \leq \bar{\theta}_{b}\left(t_{i-1}, t_{i}\right)+\bar{u}\left(t_{i}\right) \leq \bar{\theta}_{\max }
$$

Також неважко помітити, що існує безліч способів підібрати керуючий вплив для досягнення будь якого бажаного рівня $0 \leq \mu\left(t_{i}\right)<1$, введемо додатково критерій якості [4]:

$$
J\left(t_{i}\right)=J\left(\bar{u}\left(t_{i}\right)\right)=\sum_{j} u_{j}^{2}\left(t_{i}\right) \rightarrow \min
$$

Даний критерій якості означає, що ми бажаємо досягнути бажаного результату шляхом найменшого керуючого впливу на тарифікаційну систему з усіх можливих варіантів такого впливу.

Використовуючи (27) - (31) та відповідну літературу [4;5], дискретна модель оптимального управління тарифікаційною системою страхової компанії може бути описана наступним чином: 


$$
\begin{gathered}
J\left(t_{i}\right)=J\left(\bar{u}\left(t_{i}\right)\right)=\sum_{j} u_{j}^{2}\left(t_{i}\right) \rightarrow \min \\
\mu\left(\bar{\theta}_{b}\left(t_{i}, t_{i+1}\right), t_{i}\right)=\frac{(C+N+D+V+R)_{\left[t_{i-1}, t_{i}\right]}}{G\left(\bar{\theta}_{b}\left(t_{i}, t_{i+1}\right), t_{i-1}, t_{i}\right)} \rightarrow \min \\
\left\{\begin{array}{l}
\bar{\theta}_{b}\left(t_{i}, t_{i+1}\right)=\bar{\theta}_{b}\left(t_{i-1}, t_{i}\right)+\bar{u}\left(t_{i}\right) \\
\bar{\theta}_{\min } \leq \bar{\theta}_{b}\left(t_{i-1}, t_{i}\right)+\bar{u}\left(t_{i}\right) \leq \bar{\theta}_{\max }
\end{array}\right.
\end{gathered}
$$

Де:

$G\left(\bar{\theta}_{b}\left(t_{i}, t_{i+1}\right), t_{i-1}, t_{i}\right)$ - сума заробленої премії за результатами періоду $\left[t_{i-1}, t_{i}\right]$.

$\mu\left(\bar{\theta}_{b}\left(t_{i}, t_{i+1}\right), t_{i}\right)$ - відповідне значення комбінованого коефіцієнту збитковості.

Варто зауважити, що критерій якості (мінімізація керуючого впливу) i критерій оптимальності (мінімізація комбінованого коефіцієнту збитковості) знаходяться в суперечності, адже для мінімізації збитковості необхідно задіяти максимальний керуючий вплив вбік збільшення тарифів. Для уникнення даної суперечності критеріїв i спрощення розв'язку задачі оптимального керування в рамках моделі (32), можна задати бажане значення комбінованого коефіцієнта збитковості, орієнтуючись на яке i буде здійснюватися керування. Для цього підійдемо до визначення такого фіксованого рівня збитковості за принципом від оберненого - визначимо бажаний рівень прибутковості. Позначимо бажаний рівень прибутковості літерою $\eta$ і перепишемо задачу (32) у вигляді:

$$
\begin{gathered}
J\left(t_{i}\right)=J\left(\bar{u}\left(t_{i}\right)\right)=\sum_{j} u_{j}^{2}\left(t_{i}\right) \rightarrow \min \\
\mu\left(\bar{\theta}_{b}\left(t_{i}, t_{i+1}\right), t_{i}\right)=\frac{(C+N+D+V+R)_{\left[t_{i-1}, t_{i}\right]}}{G\left(\bar{\theta}_{b}\left(t_{i}, t_{i+1}\right), t_{i-1}, t_{i}\right)}=1-\eta \\
\left\{\begin{array}{l}
\bar{\theta}_{b}\left(t_{i}, t_{i+1}\right)=\bar{\theta}_{b}\left(t_{i-1}, t_{i}\right)+\bar{u}\left(t_{i}\right) \\
\bar{\theta}_{\min } \leq \bar{\theta}_{b}\left(t_{i-1}, t_{i}\right)+\bar{u}\left(t_{i}\right) \leq \bar{\theta}_{\max }
\end{array}\right.
\end{gathered}
$$

Розв’язком задачі оптимального керування в даному випадку $є$ вектор оптимального керування, за допомогою якого легко визначити нові значення базових тарифів, що відповідають шуканому оптимуму:

$$
\bar{\theta}_{b}^{*}\left(t_{i}, t_{i+1}\right), \bar{u}^{*}\left(t_{i}\right)
$$

Висновки. Результатом наукових розробок, приведених в даній статті являється створення i опис дискретної моделі оптимального керування тарифікаційною системою страхової компанії, призначенням якої $\epsilon$ розрахунок необхідного керуючого впливу на тарифікаційну систему в 
кількісному вираженні з метою утримування портфеля страхових договорів в рамках заданого рівня прибутковості.

До основних переваг отриманої математичної моделі можна віднести:

- Прив'язка моделі до реальних показників та даних, що має будь-яка страхова компанія, що робить можливим використання даної моделі на практиці без додаткових досліджень та формалізацій.

- Модель дозволяє розраховувати оптимальний керуючий вплив на тарифікаційну систему СК в будь-який момент часу $t$.

- Модель дозволяє враховувати сумарний ефект для загального портфелю договорів СК, який здійснюють сумісно окремі види страхування, якими ця СК займається.

До основних недоліків отриманої моделі можна віднести: дискретність моделі, яка не дозволяє іноді вчасно реагувати на збурення, яким може піддаватись СК; громіздкість розрахунків; використання фіксованих множин коефіцієнтів поправки на фактори ризику, що робить модель менш гнучкою i ефективною, ніж вона могла б бути.

Подальші розробки в даному напрямку плануються бути направленими вбік доопрацювання отриманої моделі 3 метою уникнення недоліків поточного варіанту цієї моделі, а також вбік аналізу можливостей врахування інтересів споживача при прийнятті рішень щодо змін тарифікаційної системи. Однак, і в отриманому вигляді модель може бути використана в практичній діяльності страхових компаній, що займаються страхуванням ризиків.

\section{Література:}

1. Березовчук О.С. Концептуальна схема функціонування страхової компанії як об’єкта керування [Електронний ресурс] / О.С. Березовчук // Ефективна економіка. - 2014. - №11. - Режим доступу до журналу: http://www.economy.nayka.com.ua

2. Осадець С.С. Страхування: Підручник / Керівник авт. колективу і наук. ред. С.С.Осадець. - Вид. 2-ге, перероб. і доп. - К.: КНЕУ, 2002. - 599 с.

3. Definition of "Combined Ratio" [Електронний ресурc] // Investopedia: [сайт] Режим доступу вільний: http://www.investopedia.com/terms/c/combinedratio.asp

4. Болтянский В.Г. Оптимальное управление дискретными системами. М.: Наука, 1973. - 446 с.

5. Левошич О. Л. Елементи теорії керування : Навч.-метод. посіб. / О. Л. Левошич, Ю. В. Крак; Київ. нац. ун-т ім. Т.Шевченка. - К., 2002. - 81 с. 